\title{
TEMPORAL VARIATIONS IN COMMUNITY STRUCTURE IN AND AROUND INTERTIDAL BARNACLE (Chthamalus challengeri Hoek) PATCHES ON A PLEBBY SHORE IN JAPAN
}

\author{
APOLINÁRIO, $\mathrm{M}$. \\ Museu Nacional, Departamento de Invertebrados, Carcinologia, Universidade Federal do Rio de Janeiro, \\ CEP 20940-040, Rio de Janeiro, RJ, Brazil \\ Correspondence to: Museu Nacional, Departamento de Invertebrados, Carcinologia, \\ e-mail: moa@nit.mtecnet.com.br, http://www.mtecnet.com.br/pessoal/moa \\ Received October 17, 1997 - Accepted May 04, 1998 - Distributed February 23, 1999
}

(With 6 figures)

\begin{abstract}
The community structure in and around two barnacle (Chthamalus challengeri Hoek) patches (sites A and B) which extended from the middle to the upper intertidal zone on a pebbly shore in Magarisaki (Amakusa, Kyushu, Japan), was studied during summer and winter of 1995 and 1996. The results show a significant decrease in the proportion of substrate covered by barnacles from January 1995 to July 1996. The number of species, number of individuals, and biomass also decreased in the patch areas through time. There were significant differences between inside and outside the patches for percentage of substrate covered by barnacles, number of individuals, number of species, and biomass during the first year. Numbers of some gastropods were significantly higher in the barnacle patches, suggesting that the presence of barnacles create favorable microhabitat for the other taxa.
\end{abstract}

Key words: barnacles, Chthamalus challengeri, community structure, intertidal, Japan.

\section{RESUMO}

\section{Estrutura de comunidades dentro e fora de agregações de cracas no litoral de Amakusa, Japão}

Durante o verão e o inverno de 1995 e 1996, foram realizados estudos de estrutura das comunidades dentro e ao redor de duas agregações de cracas (Chthamalus challengeri Hoek), nas áreas A e B, que se estendem das regiões do supra ao médio litoral em Magarisaki (Amakusa, Kyushu, Japan). Os resultados mostram um declínio significativo na proporção de substrato coberto por cracas desde janeiro de 1995 até julho de 1996. O número de espécies, número de indivíduos e biomassa também diminuíram dentro dos "patches" de cracas no decorrer do tempo. Houve significativas diferenças entre as comunidades de dentro e fora dos "patches" para porcentagem de substrato coberto por cracas, número de espécies, número de indivíduos e biomassa durante o primeiro ano de estudo. Os números de alguns gastrópodos foram significativamente maiores dentro dos "patches" de cracas, sugerindo que a presença das cracas cria um microambiente favorável a outros taxa.

Palavras-chave: cracas, Chthamalus challengeri, estrutura de comunidades, região entre-marés, Japão.

\section{INTRODUCTION}

Physical features or biological variables such as competition and predation commonly explain spatial differences and temporal changes in patchness. Differences in community structure among patches of dominant related species occur at many scales of resolution, with the smallest being the space occupied by a single organism (Sauer Machado et al., 1992). Differences in substrate also influence the structure of a community, making comparison of the results obtained by different authors difficult. For example, there is abundant literature on community structure and interactions on hard intertidal substrata, such as rocky shores, and vertical walls (Paine, 1974; 
Menge, 1976; Lubchenco \& Menge, 1978; Menge \& Lubchenco, 1981, Cubit, 1984; Underwood \& Denley, 1984; Garrity \& Levings, 1987; Sauer Machado et al., 1992, 1996), but little on boulder or pebble shores (Sousa, 1979a, e 1979b; Petersen et al., 1986; Takada \& Kikuchi, 1990, 1991; Rocha, 1995).

Benthic patchness can also be caused and/ or maintained by unpredictable factors operating in the plankton. There may be temporal variation in the larval supply (Gaines et al., 1985; Roughgarden et al., 1985, 1987) threatening the maintenance of a population.

In this work a comparison of community structure within and outside intertidal barnacle (Chthamalus challengeri Hoek) patches on a pebbly shore over time, is done by using multivariate analysis of variance (MANOVA).

\section{MATERIALAND METHODS}

\section{Study site}

The sand spit of Magarisaki, located in Amakusa Shimoshima, West Kyushu, Japan (lat. $32^{\circ} 32^{\prime} \mathrm{N}$, long. $130^{\circ} 02^{\prime} \mathrm{E}$ ) (Fig.1) is formed by oval pebbles, with an average diameter of $20 \mathrm{~cm}$, on corse sand (Takada \& Kikuchi 1990, 1991). The patches observed along the shore were of irregular size, extending from the middle to the upper intertidal zone.

The shore is relatively protected in summer (June-September), with winds predominantly from south, but exposed during winter when winds are from the north (November-February). Tidal amplitudes vary between 0 and $300 \mathrm{~cm}$, with the middle intertidal defined as 150 to $200 \mathrm{~cm}$, and the upper intertidal at 100 to $150 \mathrm{~cm}$ below mean high tide level. Mean air and surface seawater temperature range from $6^{\circ}$ to $33^{\circ}$, and $13^{\circ}$ to $26^{\circ} \mathrm{C}$, respectively (Fig. 2 ).

\section{Community structure}

The community structure was monitored within and outside the barnacle patches at sites A and B (see Fig. 1), at the two intertidal levels during winter and summer (January-July) of 1995 and 1996 using four $0.25 \mathrm{~m}^{2}$ quadrats, placed randomly on $10 \mathrm{~m}^{2}$ horizontal transect line. All organisms inside the quadrats were collected, fixed in $10 \%$ formalin, identified and measured in the laboratory.
Percentage of substrate covered by barnacles

The sites were photographed just before sampling the quadrats. In the laboratory, the photographic slides were projected onto a $0.90 \mathrm{~m}^{2}$ screen, filled with 225 evenly -spaced dots, to calculate the proportion of substrate covered by barnacles ( $=\%$ cover of barnacles). Only living individuals were included in my calculations.

\section{Data Analysis}

Multivariate analysis of variance (MANOVA), formed the base of the data analysis, using date (time), site (A, B), tidal height, and patch - non-patch (space) as the four factors. The $\%$ cover of barnacles, number of species, number of individuals, and biomass were monitored as the community indexes. The numbers of the most dominant species (gastropods) were also included in the analyses. Kendall's coefficient of rank correlation $(\mathrm{t})$, was used to examine the relationship between the mean \% cover of barnacles on the four sampling dates $(n=4)$, the mean number of species, individuals and biomass $(\mathrm{g})$, and the mean numbers of the most abundant gastropods within the barnacle patches (4 replicates) given in Burr (1960). Shannon's diversity index (H') was also calculated for data from within $(\mathrm{P})$ and outside (OP) the barnacle patches, to assess variation in the diversity index over time.

\section{RESULTS}

The fauna sampled during this study belongs to the following groups: Annelida: Polychaeta (1 specie); Arthropoda: Crustacea, Malacostraca (4 species); Mollusca: Polyplacophora (1 specie), Gastropoda (16 species); and Echinodermata: Holothuroidea (1 specie) (Table 1). Gastropods represented $70 \%$ of the total number of species; their abundance and biomass represented $95 \%$ of the total fauna sampled. There was a significant decline in the community indexes over time. The MANOVA calculated for sites (A, B), intertidal levels (upper, middle), and patches (P, OP), against time, showed significant differences for the $\%$ cover of barnacles. The differences between sites $\mathrm{A}$ and $\mathrm{B}$, as well as upper and middle intertidal levels, were caused by the decline of the $\%$ cover of barnacles at the middle intertidal patch in site B. Variations in the number of species had a similar 
pattern between the two sites, with greatest numbers at the middle intertidal, and inside the patch areas. The number of individuals did not vary sig- nificantly between the two intertidal levels. See Fig. 3 and Table 2 for the patterns of variation and the MANOVA results.

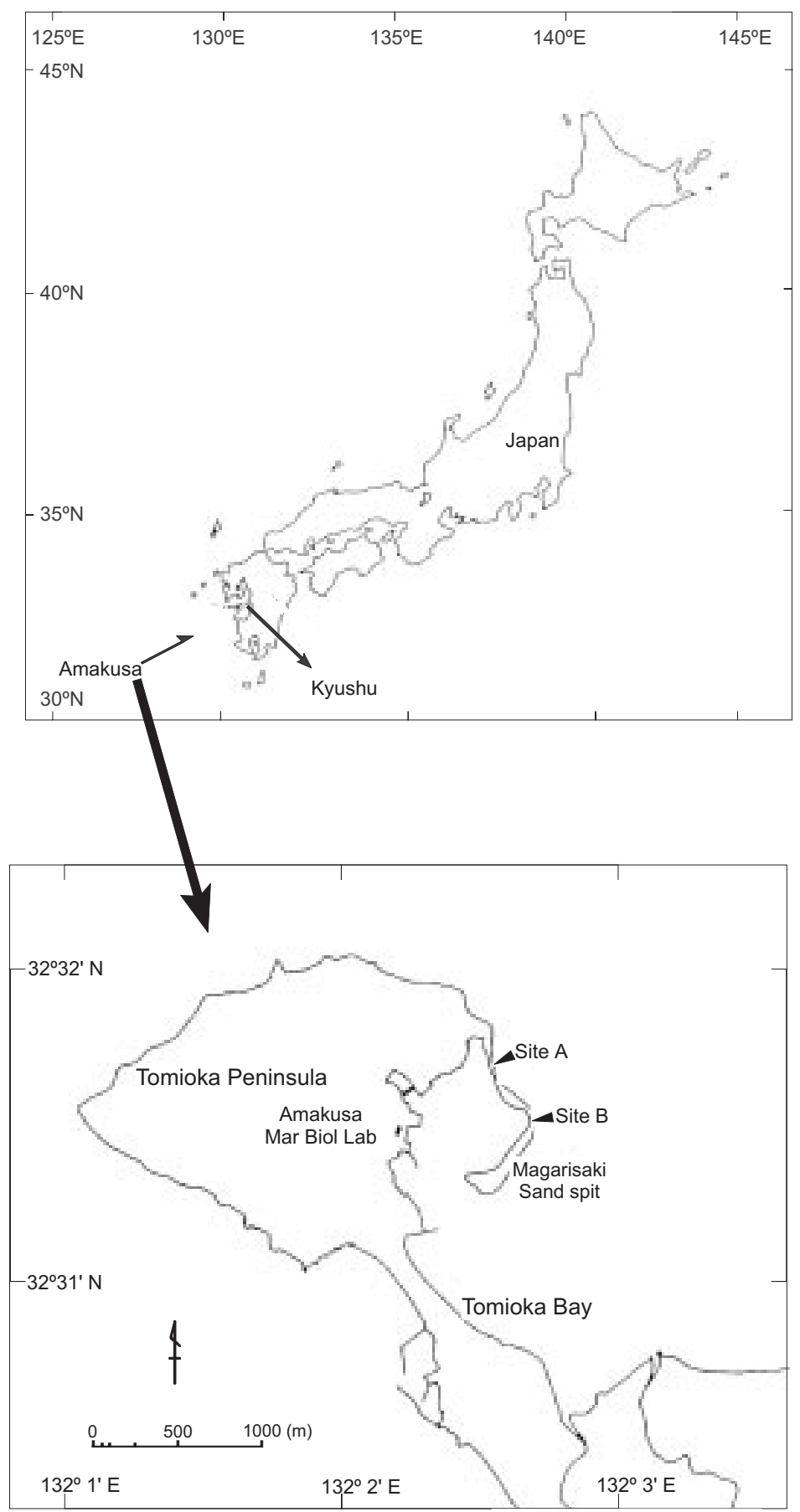

Fig 1 - Maps showing the Amakusa Islands, in Kyushu, Japan (upper), and the Magarisaki Sand Spit at Tomioka Peninsula, Amakusa (lower). 
TABLE 1

Relative frequency of species in samples from sites $A$ and $B$, at the upper and middle intertidal levels through time. $P$ and $O P$ represent samples from inside and outside the barnacle patches, respectively. $0=$ absence of species, $+=$ sampled on just one date, $++=$ sampled more than once, but not on all dates, and $+++=$ sampled on all dates.

\begin{tabular}{|c|c|c|c|c|c|c|c|c|}
\hline & \multicolumn{4}{|c|}{ Site $\mathbf{A}$} & \multicolumn{4}{|c|}{ Site B } \\
\hline & \multicolumn{2}{|c|}{ upper } & \multicolumn{2}{|c|}{ middle } & \multicolumn{2}{|c|}{ upper } & \multicolumn{2}{|c|}{ middle } \\
\hline & $\mathbf{P}$ & O P & $\mathbf{P}$ & $\mathbf{O P}$ & $\mathbf{P}$ & $\mathbf{O P}$ & $\mathbf{P}$ & $\mathbf{O P}$ \\
\hline \multicolumn{9}{|l|}{ Phylum Annelida } \\
\hline \multicolumn{9}{|l|}{ Class Polychaeta } \\
\hline \multicolumn{9}{|l|}{ Order Phyllodocida } \\
\hline \multicolumn{9}{|l|}{ Family Polynoidae } \\
\hline Harmathoe imbricata & 0 & + & 0 & 0 & 0 & 0 & ++ & ++ \\
\hline \multicolumn{9}{|l|}{ Phylum Arthropoda } \\
\hline \multicolumn{9}{|l|}{ Subphylum Crustacea } \\
\hline \multicolumn{9}{|l|}{ Class Malacostraca } \\
\hline \multicolumn{9}{|l|}{ Order Decapoda } \\
\hline \multicolumn{9}{|l|}{ Suborder Anomura } \\
\hline Pagurus laguginosos & 0 & 0 & 0 & 0 & 0 & 0 & 0 & + \\
\hline P. samuellis & 0 & 0 & + & 0 & 0 & 0 & + & 0 \\
\hline Petrolisthes japonicus & 0 & 0 & 0 & 0 & 0 & 0 & 0 & + \\
\hline \multicolumn{9}{|l|}{ Suborder Brachyura } \\
\hline Gaetice depressus & ++ & ++ & +++ & +++ & ++ & +++ & +++ & ++ \\
\hline \multicolumn{9}{|l|}{ Phylum Mollusca } \\
\hline \multicolumn{9}{|l|}{ Class Polyplacophora } \\
\hline \multicolumn{9}{|l|}{ Order Acanthochitonidae } \\
\hline \multicolumn{9}{|l|}{ Family Acanthochitonidae } \\
\hline $\begin{array}{l}\text { Acanthonchiton defilippi } \\
\text { (Tapparone-canefori) }\end{array}$ & ++ & ++ & ++ & ++ & ++ & ++ & ++ & ++ \\
\hline \multicolumn{9}{|l|}{ Class Gastropoda } \\
\hline \multicolumn{9}{|l|}{ Subclass Prosobranchia } \\
\hline Order Archeogastropoda & & & & & & & & \\
\hline Family Acmaeidae & & & & & & & & \\
\hline Notoacmea concinna (Lischke) & ++ & ++ & 0 & 0 & ++ & 0 & 0 & 0 \\
\hline N. fuscoviridis teramachii & ++ & ++ & ++ & ++ & ++ & ++ & ++ & ++ \\
\hline N. nigrans (Lischke) & ++ & ++ & ++ & ++ & ++ & ++ & ++ & ++ \\
\hline N. schrenckii (Lischke) & 0 & 0 & ++ & ++ & 0 & ++ & 0 & ++ \\
\hline Patelloida pygmea (Dunker) & ++ & ++ & ++ & ++ & ++ & ++ & ++ & ++ \\
\hline Family Trochidae & & & & & & & & \\
\hline Monodonta labio (Linnaeus) & +++ & +++ & +++ & +++ & +++ & +++ & +++ & +++ \\
\hline Omphalius rusticus (Gmelin) & 0 & + & ++ & 0 & + & 0 & + & 0 \\
\hline Family Turbinidae & & & & & & & & \\
\hline Lunella cronata coreensis (Récluz) & +++ & +++ & +++ & +++ & +++ & +++ & +++ & +++ \\
\hline Family Neritidae & & & & & & & & \\
\hline Nerita spp. & +++ & +++ & +++ & +++ & +++ & +++ & +++ & +++ \\
\hline Order Mesogastropoda & & & & & & & & \\
\hline Family Littorinidae & & & & & & & & \\
\hline Littorina brevicula (Philipi) & +++ & ++ & +++ & ++ & +++ & ++ & +++ & ++ \\
\hline Peasiella roepstorfiana (Nevill) & +++ & ++ & +++ & ++ & +++ & ++ & +++ & ++ \\
\hline Order Neogastropoda & & & & & & & & \\
\hline Family Muricidae & & & & & & & & \\
\hline Cronia fusca (Küster) & 0 & 0 & 0 & 0 & 0 & 0 & 0 & + \\
\hline
\end{tabular}




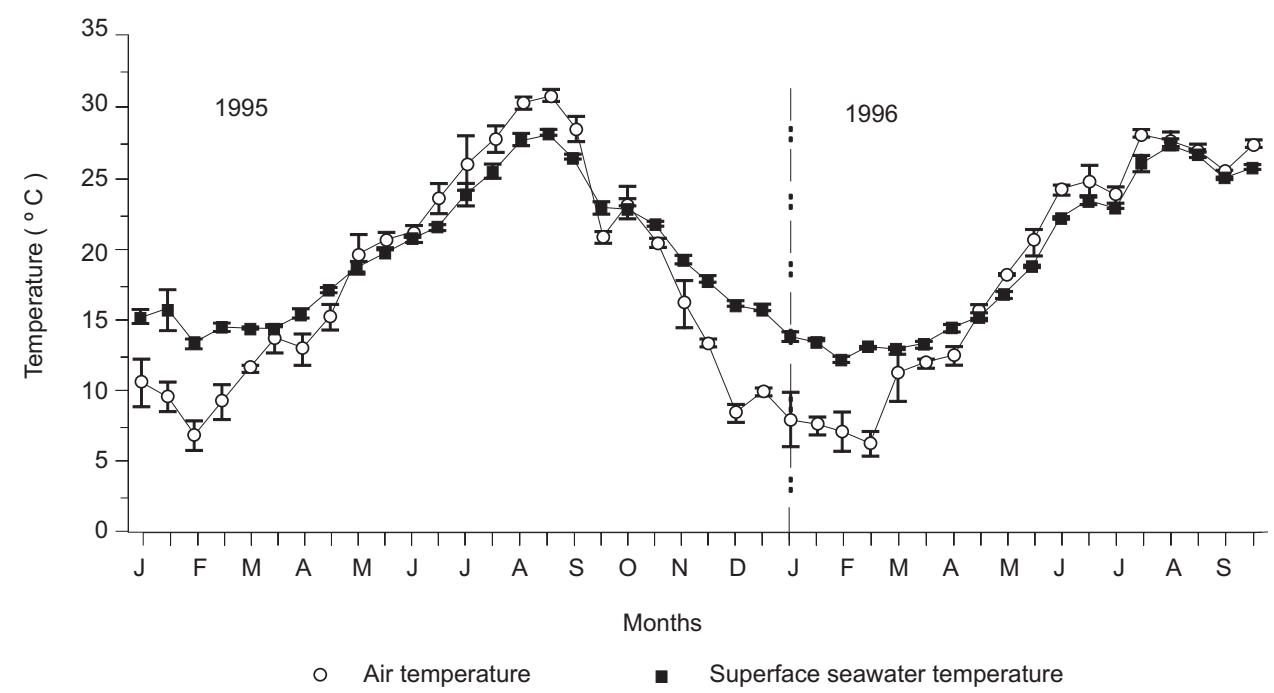

Fig. 2 - Mean (SD) air and surface seawater temperatures for January 1995 to September 1996.

TABLE 2

Summary of the MANOVA results for 4 dependent variables (\% cover, number of species, number of individuals, and biomass) calculated for sites (A, B), intertidal levels (upper, middle), and patches $(P, O P)$ against time.

\begin{tabular}{|c|c|c|c|}
\hline Source & DF & $\mathbf{F}$ & $\mathbf{P}$ \\
\hline \multicolumn{4}{|l|}{ For $\%$ cover } \\
\hline Sites $(\mathrm{A}, \mathrm{B})$ vs. Time & 3 & 2.89 & $0.0386 *$ \\
\hline Int. levels (upper, middle) vs. Time & 3 & 2.88 & $0.0393 *$ \\
\hline Patches (P, OP) vs. Time & 3 & 130.96 & $0.0001 * * *$ \\
\hline \multicolumn{4}{|l|}{ For No. of species } \\
\hline Sites $(\mathrm{A}, \mathrm{B})$ vs. Time & 3 & 7.38 & $0.0001 * * *$ \\
\hline Int. levels (upper, middle) vs. Time & 3 & 2.98 & $0.0347 *$ \\
\hline Patches (P, OP) vs. Time & 3 & 7.06 & $0.0002 * * *$ \\
\hline \multicolumn{4}{|l|}{ For No. of individuals } \\
\hline Sites $(\mathrm{A}, \mathrm{B})$ vs. Time & 3 & 1.03 & $0.3831 \mathrm{NS}$ \\
\hline Int. levels (upper, middle) vs. Time & 3 & 3.58 & $0.0167 *$ \\
\hline Patches (P, OP) vs. Time & 3 & 32.77 & $0.0001 * * *$ \\
\hline \multicolumn{4}{|l|}{ For biomass } \\
\hline Sites (A, B) vs. Time & 3 & 1.84 & $0.1448 \mathrm{NS}$ \\
\hline Int. levels (upper, middle) vs. Time & 3 & 7.99 & $0.0001 * * *$ \\
\hline Patches (P, OP) vs. Time & 3 & 2.15 & $0.0974 \mathrm{NS}$ \\
\hline
\end{tabular}

*** Significantly different at 0.001 level, * significantly different at 0.05 level, and NS not significantly different. 

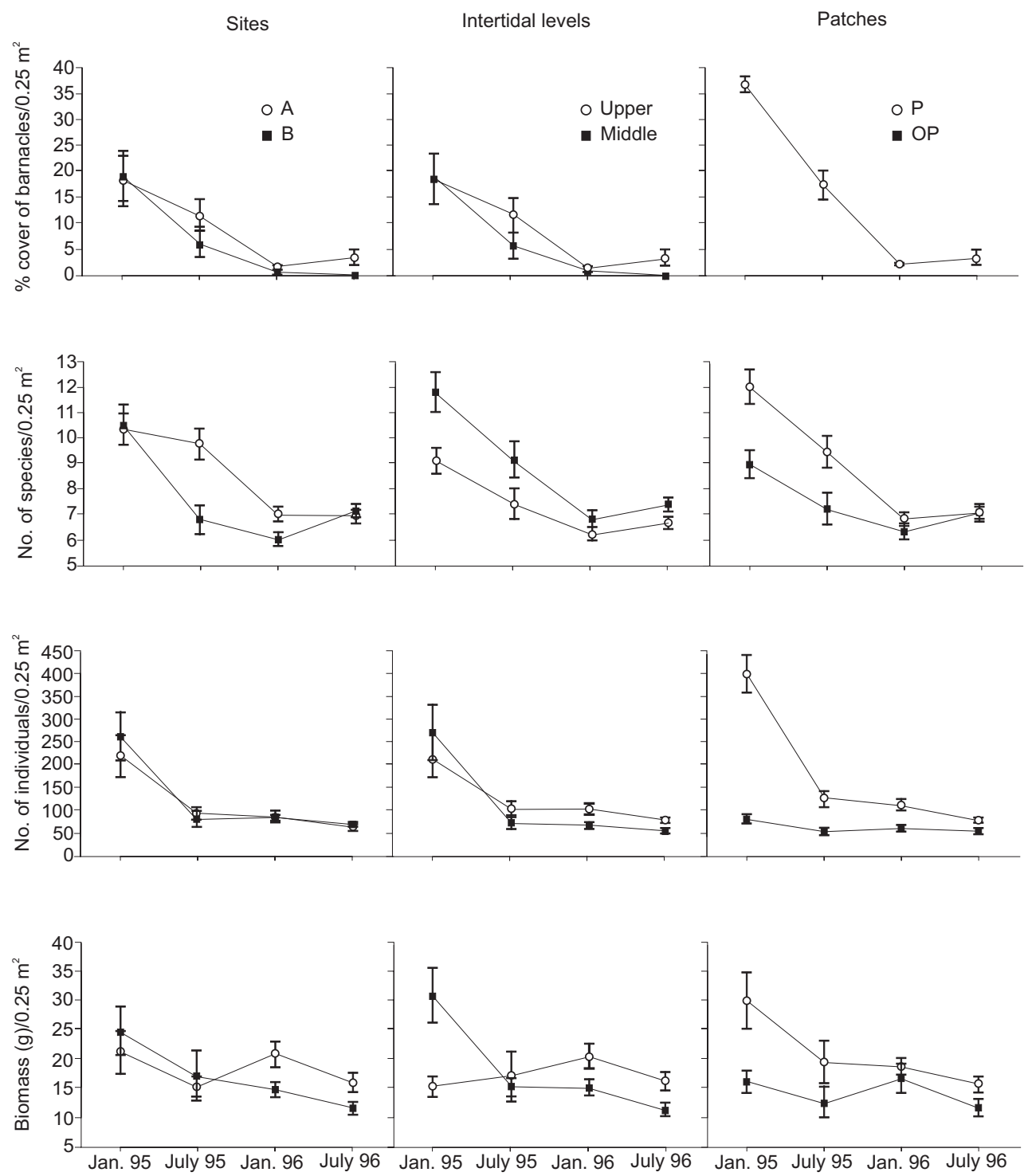

Fig. 3 - Mean (SD) \% cover of barnacles, number of species, number of individuals, and biomass (g) at sites A and $\mathrm{B}$; upper and middle intertidal levels; and inside (P) and outside (OP) the barnacle patches over time.

The most abundant species associated with the barnacle patches, the gastropods, showed the following patterns of variation. The number of Littorina brevicula was significantly greater inside than outside the barnacle patches before the decline of the $\%$ cover of barnacles. The numbers of Peasiella roepstorfiana, were significantly greater in site $\mathrm{A}$ than in site $\mathrm{B}$, and inside than outside the barnacle patches, during the first two sampling dates. The numbers of carnivorous Thais clavigera varied significantly between the two intertidal levels and patches. The above three species showed a similar pattern of temporal variation as that of the \% cover of barnacles inside the patches. See Fig. 4, and Table 3 for patterns of variation, and the Kendall's coefficient of rank correlation $(\mathrm{t})$ results.

The three other abundant species of gastropods showed no clear association with the barnacle patches. For example, the numbers of Lunella cronata coreensis were significantly greater at the middle intertidal, but showed no relationship with patches or sites. The numbers of Monodonta labio were significantly greater in site 
$\mathrm{B}$ as well as at the middle intertidal level. Numbers of M. labio in the patch areas ranged from significantly greater outside to significantly greater inside the patches inside the patches over time. Nerita spp. showed the most significant differences amongst all the abundant gastropods. They were numerically greater in site $\mathrm{A}$ at the upper intertidal and inside the patches. Their numbers in the patches increased when the $\%$ cover of barnacles declined (Fig. 5). Se Table 4 for the summary of the MANOVA results.

There were no large temporal changes in Shannon's diversity index ( $H^{\prime}$ ) for the fauna inside the barnacle patches. Outside the patches, diversity decreased from January 1995 until January 1996, but had recovered by July 1996 (Fig. 6). With the decline of the barnacle patches, the pattern of aggregation showed by some species within the patches disappeared and more homo- geneous distribution of the species within the same intertidal level was observed at the end of the study.

\section{DISCUSSION}

The barnacle patches collapsed by the end of the first year. Species composition did not differ greatly between inside and outside patch areas, but the abundance of some species did exhibit significant differences in this respect. In the first year, when the barnacle patches were clearly delimited, three species of gastropods were significantly correlated with the patches. Amongst them, were the herbivorous Littorina brevicula and Peasiella roepstorfiana. These species are known to be abundant at the upper intertidal level of boulder and rocky shores (Takada \& Kikuchi, 1990).
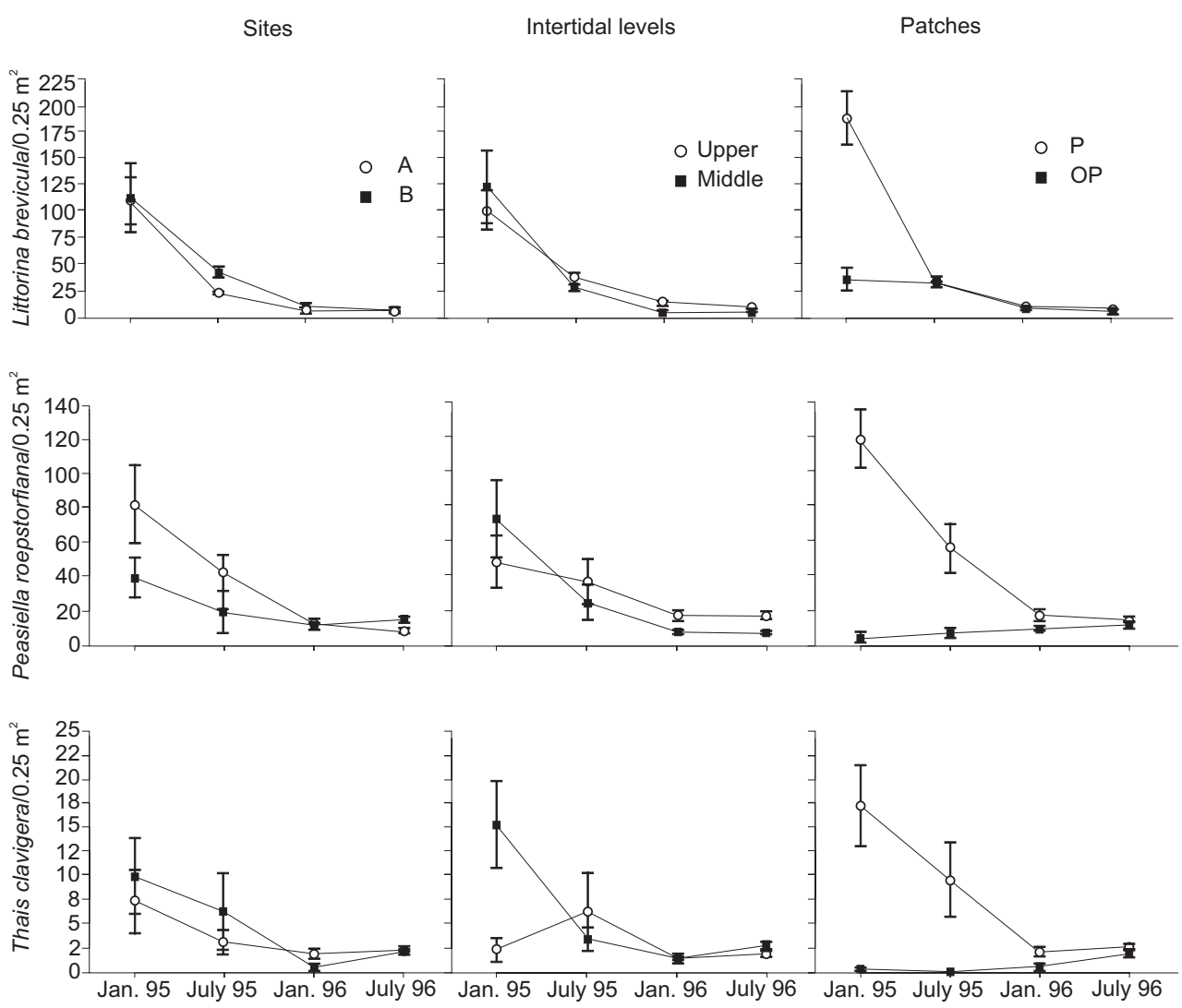

Fig. 4. - Mean (SD) numbers of three species associated with the barnacles patches (Littorina brevicula, Peasiella roepstorfiana and Thais clavigera) for sites $\mathrm{A}$ and $\mathrm{B}$; upper and middle intertidal levels; and inside $(\mathrm{P})$ and outside (OP) the barnacle patches over time. 
TABLE 3

Summary of results from Kendall's coefficient rank of correlation $(\tau)$ between the mean \% cover of barnacles during the 4 sampling dates $(n=4)$; the mean number of species, individuals, and biomass (g); as well as the mean numbers of the most abundant gastropods inside the barnacle patches during the 4 sampling dates ( 4 replicates).

\begin{tabular}{|c|c|c|}
\hline Abundances compared & $\tau$ & $\mathbf{p}$ \\
\hline \multicolumn{3}{|l|}{$\%$ cover of barnacles } \\
\hline vs. No. Species & 1.00 & $0.042 *$ \\
\hline vs. No. Individuals & 1.00 & $0.041 *$ \\
\hline vs. Biomas & 1.00 & $0.041 *$ \\
\hline vs. Littorina brevicula & 1.00 & $0.042 *$ \\
\hline vs. Peasiella roepstorfiana & 1.00 & $0.041 *$ \\
\hline vs. Thais clavigera & 0.91 & $0.174 \mathrm{NS}$ \\
\hline vs. Lunnela cronata coreensis & 0.33 & $0.496 \mathrm{NS}$ \\
\hline vs. Monodonta labio & 0.55 & $0.264 \mathrm{NS}$ \\
\hline vs. Nerita spp. & 0.54 & $0.263 \mathrm{NS}$ \\
\hline
\end{tabular}

*significantly different at 0.05 level, and NS not significantly different.
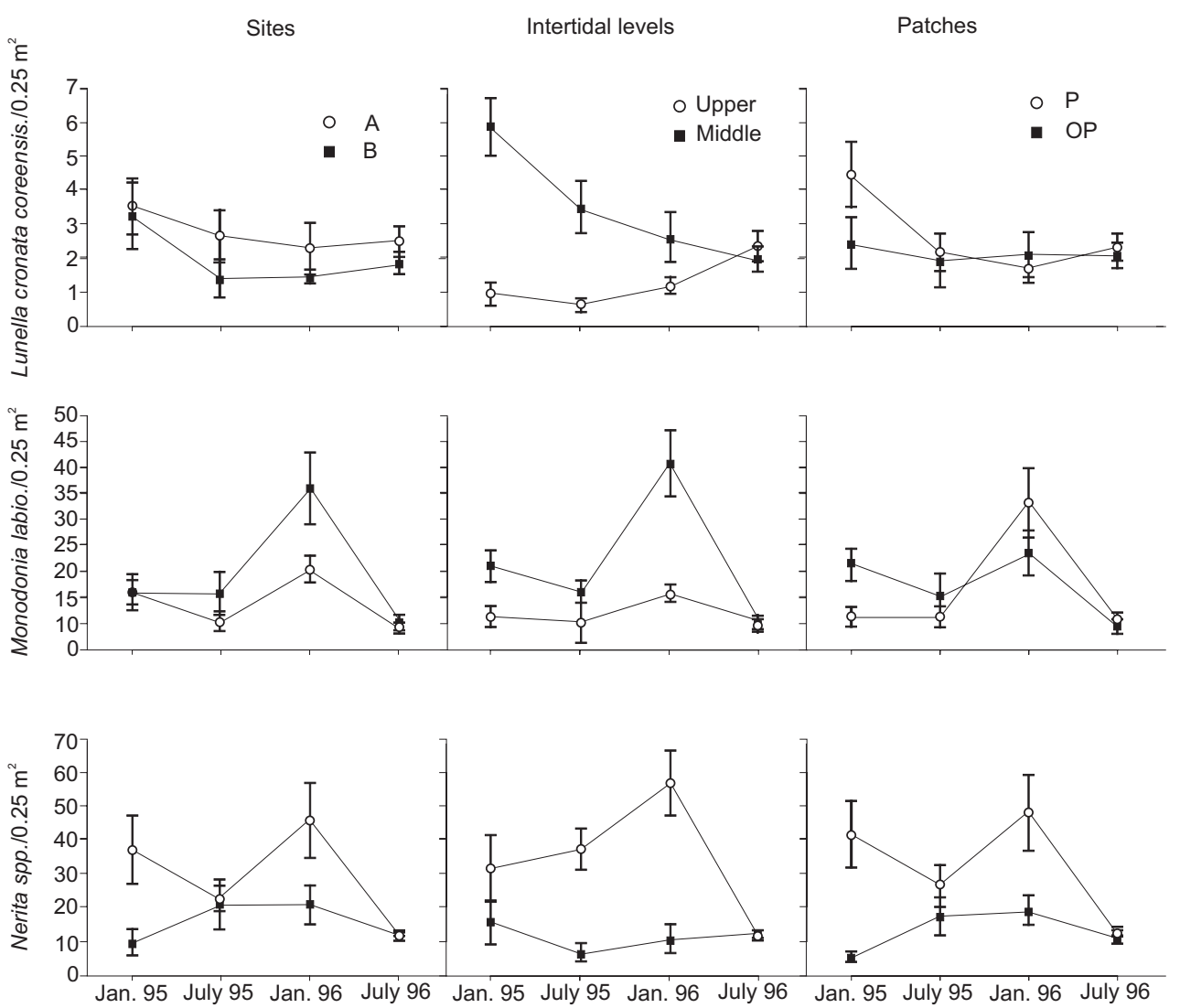

Fig. 5 - Mean (SD) numbers of abundant mobile mollusks (Lunella cronata coreensis, Monodonta labio, and Nerita spp.) for sites $\mathrm{A}$ and $\mathrm{B}$; upper and middle intertidal levels; and inside and (P) and outside (OP) the barnacle patches over time. 


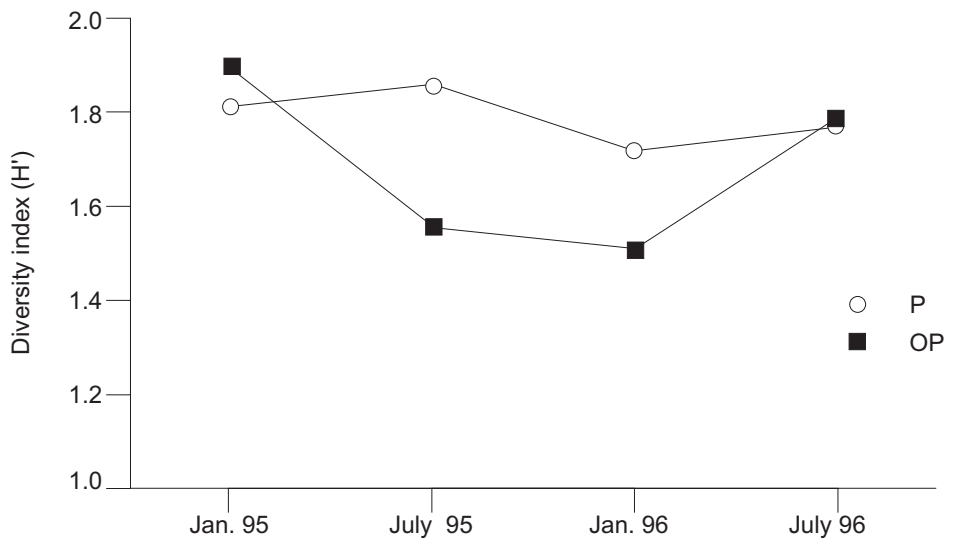

Fig. 6 - Temporal variation of Shannon's diversity index (H') for total numbers of fauna inside (P) and outside (OP) the barnacle patches.

TABLE 4

Summary of the MANOVA results for 6 dependent variables (Littorina brevicula, Peasiella roepstorfiana, Thais clavigera, Lunella cronata coreensis, Monodonta labio, Nerita spp.) calculated for sites $(A, B)$, intertidal levels (upper, middle), and patches $(P, O P)$ over time.

\begin{tabular}{|c|c|c|c|}
\hline Source & DF & $\mathbf{F}$ & $\mathbf{P}$ \\
\hline \multicolumn{4}{|l|}{ For Littorina breviculla } \\
\hline Sites (A, B) vs. Time & 3 & 0.51 & $0.7271 \mathrm{NS}$ \\
\hline Int. levels (upper, middle) vs. Time & 3 & 0.82 & $0.5160 \mathrm{NS}$ \\
\hline Patches $(\mathrm{P}, \mathrm{OP})$ vs. Time & 3 & 27.46 & $0.0001 * * *$ \\
\hline \multicolumn{4}{|l|}{ For Peasiella roepstorfiana } \\
\hline Sites (A, B) vs. Time & 3 & 5.42 & $0.0005 * * *$ \\
\hline Int. levels (upper, middle) vs. Time & 3 & 2.21 & $0.0723 \mathrm{NS}$ \\
\hline Patches $(\mathrm{P}, \mathrm{OP})$ vs. Time & 3 & 36.63 & $0.0001 * * *$ \\
\hline \multicolumn{4}{|l|}{ For Thais clavigera } \\
\hline Sites $(\mathrm{A}, \mathrm{B})$ vs. Time & 3 & 0.66 & $0.6190 \mathrm{NS}$ \\
\hline Int. levels (upper, middle) vs. Time & 3 & 6.13 & $0.0002 * * *$ \\
\hline Patches (P, OP) vs. Time & 3 & 12.97 & $0.0001 * * *$ \\
\hline \multicolumn{4}{|l|}{ For Lunella cronata coreensis } \\
\hline Sites (A, B) vs. Time & 3 & 1.18 & $0.3250 \mathrm{NS}$ \\
\hline Int. levels (upper, middle) vs. Time & 3 & 15.06 & $0.0001 * * *$ \\
\hline Patches (P, OP) vs. Time & 3 & 1.90 & $0.1157 \mathrm{NS}$ \\
\hline \multicolumn{4}{|l|}{ For Monodonta labio } \\
\hline Sites (A, B) vs. Time & 3 & 3.97 & $0.0047 * *$ \\
\hline Int. levels (upper, middle) vs. Time & 3 & 11.01 & $0.0001 * * *$ \\
\hline Patches $(\mathrm{P}, \mathrm{OP})$ vs. Time & 3 & 3.08 & $0.0190 *$ \\
\hline \multicolumn{4}{|l|}{ For Nerita spp. } \\
\hline Sites $(\mathrm{A}, \mathrm{B})$ vs. Time & 3 & 10.72 & $0.0001 * * *$ \\
\hline Int. levels (upper, middle) vs. Time & 3 & 12.49 & $0.0001 * * *$ \\
\hline Patches (P, OP) vs. Time & 3 & 13.63 & $0.0001 * * *$ \\
\hline
\end{tabular}

*** Significantly different at 0.001 level, ** significantly different at 0.01 level, *significantly different at 0.05 level, and NS not significantly different. 
The littorinids tend to use the barnacle tests as a refuge, and so as a source of food by grazing on the microalgae associated with the barnacles' tests (Apolinário et al.). The other associated gastropod was Thais clavigera, a potential predator of the barnacles. Its abundance within the patches could be an important factor in patch formation, according to the predation hypothesis proposed by Paine (1974, 1977). However, the predation hypothesis was based on studies done on rocky shores, where zonation is well delimited, and competition for space amongst the sessile intertidal organisms (barnacles, mussels, and microalgaes) is very intensive. Also, Chthamalus spp. is less susceptible to either bulldozing or predation by gastropods (Dayton, 1971; Paine, 1966, 1981). In other hand, Connell (1961a), observed that predation by Thais lapillus influences the dynamics of natural populations of Balanus ballanoides. The scenario of our study is completely different, especially in the absence of space limitation on the Magarisaki Sand Spit, due to high tidal amplitude and low inclination profile.

The results from Kendall's coefficient of rank correlation must be interpreted carefully. A significant correlation per se does not mean a cause/effect relationship. For example, many factors such as timing of recruitment and mortality of these populations (Takada \& Kikuchi, 1991) could be operating concurrently with the decreasing \% cover of barnacles. However, considering the sequence of events from the beginning of the study, when there were well delimited barnacle patches, to the last sampling date, when the patches had disappeared, my suggestion is that factors operating on the barnacle population prior to their patchy recruitment were the principal causes of the observed patterns, i. e. the differences in the community structures were a consequence of and not the cause of the appearance of the barnacle patches.

Acknowledgements - I express my sincere gratitude to Prof. Taiji Kikuchi for giving me the chance to develop this project in Japan, and to my advisor Dr. Keisuke Mori for his valuable suggestions and teachings. I also express my gratitude to $\mathrm{Mr}$ Teruo Sameshima for his technical support. Thanks to all professors, colleagues, and staff members at the Amakusa Marina Biological Laboratory who helped me to settle in the town and develop my research. Thanks also to Dr. Rich- ard Weisburd and Dr. Jay Maclean for English language revision. The Japanese Ministry of Science and Culture (MONBUSHO) provided financial assistance for my stay in Japan.

\section{REFERENCES}

APOLINÁRIO, M., COUTINHO, R. \& BAETA NEVES, M.H., Periwinkle (Gastropode: Littorimidae) habitat selection and its impact upon microalgal populations. (Accepted for publication in Revista Brasileira de Biologia).

BURR, E. J., 1960, The distributions of Kendall's score S for a pair of tied rankings. Biometrika, 47: 151-171.

CONNELL, J. A., 1961a, Effects of competition, predation by Thais lapillus, and other factors on natural populations of the barnacle Balanus ballanoides. Ecol. Monogr., 31: 61-104.

CUBIT, J. D., 1984, Herbivory and the seasonal abundance of algae on a high intertidal rocky shore. Ecology, 65: 1904-1917.

DAYTON, P. K., 1971, Competition, disturbance and community organization: the provision and subsequent utilization of space in a rocky intertidal community. Ecol. Monogr., 41: 351-389.

GAINES, S., BROWN, S. \& ROUGHGARDEN, J., 1985, Spatial variation in larval concentrations as cause of spatial variation in settlement for the barnacle, Balanus glandula. Oecologia (Berlin), 67: 267-272.

GARRITY, S. D. \& LEVINGS, S. C., 1987, A predator-prey interaction between two physically and biologically constrained tropical rocky shore gastropods: direct, indirect and community effects. Ecol. Monogr., 51: 267-286.

LUBCHENCO, J. \& MENGE, B. A., 1978, Community development and persistence in a low rocky intertidal zone. Ecol. Monogr., 48: 67-94.

MENGE, B. A., 1976, Organization of the New England rocky intertidal community: role of predation, competition and environmental heterogeneity. Ecol. Monogr., 46: 355-393.

MENGE, B. A. \& LUBCHENCO, J., 1981, Community organization in temperate and tropical rocky intertidal habitats: prey refuges in relation to consumer pressure gradients. Ecol. Monogr., 51: 429-450.

PAINE, R. T., 1966, Food web complexity and community stability. Am. Nat., 103: 91-93.

PAINE, R. T., 1974, Intertidal community structure: experimental studies on the relationship between a dominant competitor and its principal prey. Oecologia (Berlin) 15: 93-120.

PAINE, R. T., 1977, Controlled manipulations in the marine intertidal zone, and their contribution to ecological theory, pp. 245-270. In: C. E. Goulden (ed.). The changing scenes in natural sciences, 1776-1976. Special publication 12, The Academy of Natural Sciences of Philadelphia, Fulton, Lancaster, Pennsylvania, USA. 
PAINE, R. T., 1981, Barnacle ecology: linkage, interaction strength and community infrastructure. J. Anim. Ecol. 49: 667-685.

PETERSEN, J. A., SUTHERLAND, J. P. \& ORTEGA, S., 1986, Patch dynamics of mussel beds near São Sebastião (São Paulo), Brazil. Mar. Biol, 93: 389-393.

ROCHA, R. M., 1995, Abundance and distribution of sessile invertebrates under intertidal boulders (São Paulo, Brazil). Bol. Inst. Oceanogr., São Paulo 43(1): 71-85.

ROUGHGARDEN, J., IWASA, Y. \& BAXTER, C., 1985. Demographic theory for an open marine population with space limited recruitment. Ecology, 66: 54-67.

ROUGHGARDEN, J., GAINES, D. \& PACALA, S. W., 1987, Supply-side ecology: the role of physical transport processes, pp. 491-581. In: P. Giller and J. Gee (eds), Organization of communities: past and present. Proceedings of the British Ecological Society Symposium, Aberystwyth, Wales (April, 1986), Blackwell Scientific, London, England.

SAUER MACHADO, K. R. S., CHAPMAN, A. R. O. \& COUTINHO, R., 1992, Patch structure in a tropical rocky shore community in Brazil: a mosaic of successional states? OPHELIA, 35(3): 187-195.

SAUER MACHADO, K. R. S., CHAPMAN, A. R. O. \& COUTINHO, R., 1996, Consumer species have limited and variable roles in community organization on a tropical intertidal shore. Mar. Ecol. Prog. Ser., 134: $73-83$.
SOUSA, W. P., 1979a, Disturbance in marine intertidal boulder fields: the nonequilibrium maintenance of species diversity. Ecology, 60: 1225-1239.

SOUSA, W. P., 1979b., Experimental investigations of disturbance and ecological succession in a rocky intertidal algal community. Ecol. Monogr., 49: 227-254.

TAKADA, Y. \& KIKUCHI, T., 1990, Mobile molluscan communities in boulder shores and the comparison with other intertidal habitats in Amakusa. Publ. Amakusa Mar. Biol. Lab. 10: 145-168.

TAKADA, Y. \& KIKUCHI, T., 1991, Seasonal and vertical variation of the boulder shore fauna in Amakusa. Publ. Amakusa Mar. Biol. Lab., 11(1): 1-17.

UNDERWOOD, A. J. \& DENLEY, E. J., 1984, Paradigms, explanations and generalizations in models for the structure of intertidal communities on rocky shores, pp. 151-180, In: D. R. Strong, D. Simberloff, L. G. Abele \& A. B. Thistle (eds.), Ecological communities: conceptual issues and evidence, Princeton University Press, Princeton, New Jersey, USA. 